\title{
PENGEMBANGAN PERANGKAT PEMBELAJARAN INKUIRI TERBIMBING BERBANTUAN SIMULASI KOMPUTER MATERI ATOM, ION, DAN MOLEKUL UNTUK MENINGKATKAN HASIL BELAJAR SISWA SMP
}

\author{
Syahri $^{1)}$, Madlazim ${ }^{2}$, Fida Rachmadiarti ${ }^{3)}$ \\ ${ }^{1)}$ Program Studi Pendidikan Sains, Program Pascasarjana Universitas Negeri Surabaya, \\ ${ }^{2}$ Dosen Program Studi Pendidikan Sains, Program Pascasarjana Universitas Negeri Surabaya \\ ${ }^{3)}$ Dosen Program Studi Pendidikan Sains, Program Pascasarjana Universitas Negeri Surabaya \\ e-mail: syahri.indonesia@gmail.com
}

\begin{abstract}
Abstrak: Penelitian ini bertujuan untuk menghasilkan perangkat pembelajaran inkuiri terbimbing berbantuan simulasi komputer yang layak untuk meningkatkan hasil belajar siswa sekolah menengah pertama (SMP). Aplikasi simulasi komputer yang digunakan terdiri dari PhET (Sims Build an Atom), Jmol, dan Periodic Table. Pengembangan perangkat pembelajaran menggunakan desain perangkat model Dick \& Carey. Subyek penelitian adalah perangkat pembelajaran yang terdiri dari silabus, RPP, LKS, buku ajar siswa dan instrumen penilaian hasil belajar. Uji coba perangkat pembelajaran diimplementasikan terhadap siswa kelas IX SMP. Teknik pengumpulan data menggunakan angket, observasi, dan tes. Teknik analisis data menggunakan analisis statistik deskriptif kualitatif dan kuantitatif. Hasil analisis data penelitian menunjukkan bahwa: (1) perangkat pembelajaran yang dikembangkan sangat valid; (2) pembelajaran terlaksana dengan kategori sangat baik; (3) hasil belajar siswa pada aspek pengetahuan mengalami peningkatan dengan skor $\mathrm{N}$-gain berkategori tinggi; dan (4) siswa memberikan respon positif terhadap pembelajaran. Berdasarkan hasil penelitian tersebut, dapat disimpulkan bahwa perangkat pembelajaran model inkuiri terbimbing berbantuan simulasi komputer yang telah dikembangkan layak digunakan untuk meningkatkan hasil belajar siswa.
\end{abstract}

Kata Kunci: perangkat pembelajaran, inkuiri terbimbing, simulasi komputer, hasil belajar.

\begin{abstract}
This research aims to produce a feasible guided inquiry instructional materials by using computer simulation to improve student's learning achievement of junior high school. The application of computer simulation used consists of PhET (Sims Build an Atom), Jmol, and Periodic Table. Development of this instructional material refers to Dick and Carey's model. The subjects of this research was instructional materials that consist of syllabus, lesson plan, student's worksheet, textbook, and achievement test. It was conducted to IX grade students in junior high school. The data were collected using questionnaire, observation, and test. The data were analyzed using descriptive qualitative and quantitative statistic technique. The results of this research reveal that: (1) the instructional materials which is developed categorized very valid; (2) learning implementation categorized very good; (3) cognitive domain of the students' learning achievement have increased by a score of N-gain high category; and (4) the students responded positively towards learning. Based on this results, it can be concluded that the guided inquiry instructional materials by using computer simulation which have been developed feasible used to improve student's learning achievement.
\end{abstract}

Keywords: instructional materials, guided inquiry, computer simulation, learning achievement.

\section{PENDAHULUAN}

Tujuan pendidikan nasional yang termaktub di dalam Undang-undang Nomor 20 Tahun 2003 Tentang Sistem Pendidikan Nasional menyatakan bahwa pendidikan nasional bertujuan untuk mengembangkan potensi peserta didik agar menjadi manusia yang beriman dan bertakwa kepada Tuhan Yang Maha Esa, berakhlak mulia, sehat, berilmu, cakap, kreatif, mandiri, dan menjadi warga negara yang demokratis serta bertanggung jawab. Dengan demikian, dibutuhkan sistem pendidikan yang dapat mengembangkan semua aspek tersebut secara terpadu, tidak hanya bersifat parsial atau memberikan prioritas pada aspek tertentu saja.

Mewujudkan tujuan pendidikan nasional bukanlah perkara yang mudah. Dibutuhkan rancangan kurikulum yang sesuai untuk mengembangkan kompetensi siswa pada semua aspek di setiap mata pelajaran serta dapat menyesuaikan dengan tuntutan perkembangan zaman. Selain itu, kerjasama yang sinergis antara setiap komponen yang terlibat dalam upaya mewujudkan tujuan pendidikan nasional tersebut juga sangat dibutuhkan untuk mendorong implementasi kurikulum.

Kurikulum 2013 merupakan penyempurnaan terhadap kurikulum sebelumnya yang dibuat sebagai

Pengembangan Perangkat Pembelajaran Inkuiri 
upaya untuk mensinergikan sistem pendidikan di Indonesia dengan tuntutan perkembangan zaman serta kebutuhan masyarakat baik di tingkat lokal maupun global. Di dalam kurikulum 2013, dikembangkan dua modus proses pembelajaran yaitu proses pembelajaran langsung dan proses pembelajaran tidak langsung.

Ilmu Pengetahuan Alam (IPA) merupakan salah satu komponen mata pelajaran dalam kurikulum 2013. Dimensi IPA berkaitan dengan upaya memahami berbagai fenomena alam secara sistematis, mencakup sikap ilmiah, proses ilmiah (metode ilmiah), produk dan aplikasi IPA. Menurut Abruscato dan DeRosa (2009:11), IPA (sains) terdiri dari dua komponen yaitu: 1) pencarian penjelasan secara sistematis; dan 2) bangunan pengetahuan yang bersifat dinamis yang dihasilkan dari pencarian secara sistematis tersebut. Dengan demikian, pembelajaran IPA bukan sekedar mengajarkan sekumpulan konsep, hukum atau teori sains tertentu melainkan juga harus membimbing siswa untuk merumuskan atau menemukan metode yang dapat digunakan untuk membangun suatu konsep sains.

Kurikulum 2013 secara eksplisit telah menekankan bahwa pembelajaran IPA sebaiknya menggunakan pendekatan inkuiri (scientific inquiry) untuk menumbuhkan kemampuan berpikir, bekerja, dan bersikap ilmiah serta mengembangkan keterampilan proses sains melalui pemberian pengalaman belajar secara langsung. Namun demikian, fakta di lapangan menunjukkan bahwa masih banyak guru IPA yang membelajarkan materi tanpa menggunakan model inkuiri dan hanya mengomunikasikannya kepada siswa baik secara lisan (ceramah) maupun menggunakan software presentasi seperti Microsoft Power Point dengan pertimbangan bahwa teknik tersebut lebih efisien. Aktivitas dalam pembelajaran seperti ini tentu saja masih didominasi oleh guru sehingga ruang bagi siswa untuk berpatisipasi secara aktif dalam kegiatan pembelajaran menjadi sedikit. Pengelolaan kelas seperti yang tergambar di atas berimbas terhadap rendahnya hasil belajar dan ketertarikan siswa terhadap kegiatan pembelajaran.

Terkait dengan materi atom, ion, dan molekul, nilai hasil belajar aspek pengetahuan pada ulangan harian siswa di sekolah tempat penelitian ini menunjukkan bahwa pada tahun ajaran sebelumnya, kurang lebih 30 persen siswa masih belum mencapai nilai KKM sehingga harus diadakan pembelajaran remedial. Keadaan ini menunjukkan bahwa pemahaman konsep siswa terhadap materi tersebut masih rendah. Rendahnya hasil belajar ini dipengaruhi oleh kurang efektifnya model dan media yang digunakan dalam kegiatan pembelajaran. Hal ini didukung oleh hasil wawancara peneliti dengan beberapa orang siswa yang menunjukkan bahwa dalam

Pengembangan Perangkat Pembelajaran Inkuiri Terbimbing Berbantuan Simulasi ........... pembelajaran materi atom, ion, dan molekul, guru belum menggunakan media yang dapat menampilkan konsepkonsep tentang atom secara lebih konkrit.

Permasalahan pengelolaan kegiatan pembelajaran yang belum berorientasi kepada siswa (student oriented) dapat diatasi dengan menerapkan model pembelajaran inkuiri yang memungkinkan siswa terlibat secara aktif dalam melakukan berbagai kegiatan seperti observasi, penyelidikan, dan percobaan. Inkuiri tidak sekedar berkaitan dengan kemampuan menjawab pertanyaan atau memperoleh jawaban yang benar tetapi membutuhkan adanya penyelidikan, eksplorasi, pencarian, penyingkapan, penelitian, penelusuran dan proses belajar (Kuhlthau dkk, 2007:2). Lebih lanjut Kuhlthau dkk (2007:2) mengatakan bahwa meskipun terkadang inkuiri merupakan kegiatan penyingkapan secara individu, tetapi lebih efektif jika melibatkan kelompok-kelompok belajar, sehingga di dalamnya terjadi interaksi sosial. Namun, tanpa bimbingan guru, hal itu cukup sulit untuk dilakukan.

Model pembelajaran inkuiri yang digunakan dalam penelitian ini adalah inkuiri terbimbing (guided inquiry) yang didasarkan pada klasifikasi tingkatan inkuiri menurut Banchi dan Bell. Menurut Banchi dan Bell (2008:27), pada pembelajaran inkuiri terbimbing, guru hanya menyiapkan pertanyaan penelitian atau rumusan masalah, sedangkan siswa merancang prosedur (metode) untuk menguji pertanyaan atau hipotesis mereka, serta membuat penjelasan. Namun demikian, siswa tetap membutuhkan bimbingan terkait dengan prosedur yang mereka rancang. Senada dengan itu, Brown dkk (dalam Opara dan Oguzor, 2011:192) menyatakan bahwa inkuiri terbimbing merupakan salah satu bentuk inkuiri dimana guru merancang skenario pembelajaran, memaparkan masalah kemudian mengerucutkannya dalam bentuk pertanyaan. Selanjutnya siswa merancang metode/prosedur pemecahan masalah untuk menjawab pertanyaan dengan bimbingan dari guru.

Fase atau tahapan kegiatan inkuiri yang digunakan dalam penelitian ini mengacu kepada fase-fase inkuiri menurut Eggen dan Kauchak (2012:241) yang terdiri dari: (1) mengidentifikasi pertanyaan; (2) merumuskan hipotesis; (3) mengumpulkan dan menganalisis data; dan (4) menilai hipotesis dan membuat generalisasi.

Pembelajaran inkuiri terbimbing disandarkan pada teori-teori belajar konstruktivis seperti teori konstruktivisme John Dewey yang menekankan bahwa siswa harus membangun pengetahuannya sendiri, teori penemuan Jerome S. Bruner yang menyarankan agar siswa berpartisipasi secara aktif dalam pembelajaran untuk memperoleh pengalaman dan melakukan eksperimen yang memungkinkan siswa menemukan $\begin{array}{lllll}\text { pengetahuan secara mandiri, serta teori } & \text { zona } \\ & & & 1371\end{array}$ 
perkembangan proximal Lev Vigotsky yang menekankan pada aspek sosial pembelajaran sehingga dengan bantuan yang sesuai (scaffolding) dari siswa lain atau guru, seorang siswa dapat memahami pengetahuanpengetahuan baru.

Keberhasilan pembelajaran tentu saja tidak hanya ditentukan oleh model pembelajaran saja, tetapi juga ditunjang oleh media yang digunakan. Keberadaan media merupakan hal yang urgen dalam pembelajaran. Media pengajaran dapat mempertinggi proses belajar siswa dalam pengajaran yang pada gilirannya diharapkan dapat mempertinggi hasil belajar yang dicapainya (Sudjana dan Rivai, 2013:2).

Salah satu jenis media yang populer saat ini adalah media simulasi virtual berbasis komputer/smartphone. Hal ini dimungkinkan karena komputer PC (desktop/ notebook/ netbook/ ultrabook) maupun smartphone sudah sangat familiar di masyarakat. Menurut Bell dkk (2008:23), simulasi komputer adalah model dinamis yang dihasilkan oleh komputer untuk menampilkan suatu teori atau model sederhana dari bagian-bagian dunia-nyata, peristiwa, atau suatu proses. Simulasi komputer dapat mengandung animasi, visualisasi, dan pengalaman laboratorium yang bersifat interaktif.

Beberapa keuntungan menggunakan simulasi komputer antara lain: (1) siswa dapat bekerja seolah-olah berada pada situasi sesungguhnya; (2) memungkinkan siswa untuk memahami berbagai interaksi kompleks terkait faktor-faktor pada lingkungan fisik maupun sosial; (3) membuat waktu lebih efisien; dan (4) konsep-konsep abstrak dapat dibuat menjadi konkret serta proses atau peristiwa tersembunyi dapat dibuat menjadi kasat mata. (Bell dkk, 2008:23).

Aplikasi simulasi komputer yang digunakan dalam penelitian ini terdiri dari PhET (Physics Environment Technology), Jmol, dan Periodic Table. Sims PhET yang digunakan adalah sims Build an Atom yang dimanfaatkan oleh siswa untuk membuat atom secara virtual, mempelajari struktur atom, ciri-ciri partikel-partikel penyusun atom, massa, muatan, serta nomor atom. Aplikasi Jmol digunakan untuk menampilkan model molekul beberapa senyawa, sedangkan aplikasi periodic table digunakan untuk mempelajari konfigurasi elektron unsur-unsur, jumlah elektron valensi dan letak unsur dalam sistem periodik unsur-unsur. Ketiga aplikasi tersebut bersifat interaktif sehingga memungkinkan siswa dapat memanipulasi berbagai variabel (parameter) aplikasi sehingga siswa dapat bereksperimen dan berkreasi selama kegiatan praktikum virtual. Sebagai contoh, dengan sims Build an Atom siswa dapat membuat beberapa jenis unsur dan ion dengan jalan memanipulasi jumlah proton, neutron, maupun elektron yang digunakan.
Berdasarkan uraian di atas, penelitian ini difokuskan untuk mengembangkan perangkat pembelajaran inkuiri terbimbing berbantuan simulasi komputer materi atom, ion, dan molekul yang layak diimplementasikan untuk meningkatkan hasil belajar siswa SMP. Kelayakan yang dimaksud ditinjau dari aspek validitas perangkat pembelajaran yang dikembangkan, aspek kepraktisan perangkat pembelajaran yang meliputi keterlaksanaan pembelajaran dan respon siswa terhadap pembelajaran, serta aspek keefektifan perangkat pembelajaran yang meliputi perkembangan sikap spiritual dan sosial siswa, peningkatan hasil belajar pengetahuan siswa, dan perkembangan aspek keterampilan proses sains siswa.

\section{METODE PENELITIAN}

Penelitian ini termasuk penelitian pengembangan yang mengembangkan perangkat pembelajaran model inkuiri terbimbing berbantuan simulasi komputer materi atom, ion, dan molekul. Perangkat pembelajaran yang dikembangkan terdiri dari Rencana Pelaksanaan Pembelajaran (RPP), Lembar Kegiatan Siswa (LKS), buku ajar siswa, serta lembar penilaian hasil belajar aspek sikap (spiritual dan sosial), pengetahuan, dan keterampilan. Pengembangan perangkat pembelajaran merupakan adaptasi dari model Dick \& Carey dengan menambahkan tahap validasi yang bertujuan untuk menilai validitas perangkat pembelajaran yang dikembangkan sebelum diimplementasikan dalam kegiatan pembelajaran. Penelitian dilaksanakan di SMP Negeri 5 Pamboang, Kabupaten Majene, Provinsi Sulawesi Barat dengan jumlah sampel sebanyak 24 orang siswa kelas IX.

Pengumpulan data dilaksanakan dengan menggunakan teknik observasi, tes, dan angket. Observasi digunakan untuk memperoleh data keterlaksanaan RPP dan data hasil belajar aspek sikap spiritual dan sikap sosial. Tes yang terdiri dari pretest dan posttest digunakan untuk memperoleh data terkait aspek pengetahuan siswa sebelum dan setelah kegiatan pembelajaran. Teknik tes juga digunakan untuk memperoleh data hasil belajar aspek keterampilan siswa. Aspek keterampilan yang dinilai adalah keterampilan proses sains yang meliputi kemampuan: (1) mengorganisakan data; (2) menganalisis data; dan (3) membuat kesimpulan, serta aspek sistematika laporan

Teknik angket digunakan untuk memperoleh data validitas perangkat pembelajaran serta data respon siswa terhadap pembelajaran. Data yang diperoleh berupa data validitas perangkat pembelajaran, data pengamatan keterlaksanaan pembelajaran, data respon siswa terhadap komponen-komponen pembelajaran, data hasil belajar 
aspek sikap spiritual dan sosial, data hasil belajar aspek pengetahuan, serta data hasil belajar aspek keterampilan.

Teknik analisis data menggunakan analisis statistik deskriptif kualitatif dan kuantitatif. Data yang dianalisis terdiri dari data validitas perangkat pembelajaran. data kepraktisan perangkat pembelajaran, dan data keefektifan perangkat pembelajaran. Skor validasi terhadap perangkat pembelajaran yang diberikan oleh dua orang validator dirata-ratakan dan dipersentasekan kemudian dicocokkan dengan kriteria validitas perangkat pembelajaran pada Tabel 1 berikut:

Tabel 1. Kriteria Validitas Perangkat Pembelajaran

\begin{tabular}{|c|c|c|}
\hline No. & Kriteria & Kategori Validitas \\
\hline 1 & $85,01 \%-100 \%$ & $\begin{array}{c}\text { Sangat valid } \\
\text { (dapat digunakan tanpa revisi) }\end{array}$ \\
\hline 2 & $70,01 \%-85 \%$ & $\begin{array}{c}\text { Cukup valid } \\
\text { (dapat digunakan dengan } \\
\text { sedikit revisi) }\end{array}$ \\
\hline 3 & $50,01 \%-70 \%$ & $\begin{array}{c}\text { Kurang valid } \\
\text { (disarankan tidak digunakan } \\
\text { karena perlu revisi besar) }\end{array}$ \\
\hline 4 & $01,00 \%-50 \%$ & $\begin{array}{c}\text { Tidak valid } \\
\text { (tidak boleh digunakan) }\end{array}$ \\
\hline
\end{tabular}

(Akbar, 2013, p. 155)

Untuk mengetahui koefisien (indeks) kesepakatan antara dua validator, digunakan teknik pengetesan kesepakatan antar validator (penilai) (inter-rater agreement). Rumus yang digunakan adalah rumus dari Cohen's Kappa sebagai berikut:

$$
\kappa=\frac{P_{o b s}-P_{\text {exp }}}{1-P_{\text {exp }}}
$$

Keterangan:

(Bakerman dan Gottman, 1997:62)

$\kappa=$ koefisien Cohen's Kappa

$P_{o b s}=$ proporsi frekuensi sepakat antar pengamat (penilai)

$P_{\text {exp }}=$ proporsi peluang sepakat antar pengamat (penilai)

Selanjutnya nilai $\kappa$ yang diperoleh dicocokkan dengan kriteria Kappa pada Tabel 2 berikut.

Tabel 2. Kriteria Nilai Kappa ( $\kappa)$

\begin{tabular}{|c|l|}
\hline Kappa Statistic & Strength of Agreement \\
\hline$<0,00$ & Poor \\
\hline $0,00-0,20$ & Slight \\
\hline $0,21-0,40$ & Fair \\
\hline $0,41-0,60$ & Moderate \\
\hline $0,61-0,80$ & Substantial \\
\hline $0,81-1,00$ & Almost Perfect \\
\hline
\end{tabular}

(Landis dan Koch, 1977:165)

Data keterlaksanaan RPP juga dianalisis dengan merata-ratakan skor keterlaksanaan RPP selama tiga kegiatan pembelajaran yang diberikan oleh dua orang observer. Skor rata-rata tersebut kemudian dicocokan dengan Tabel 3 tentang kriteria keterlaksanaan RPP sebagai berikut.
Tabel 3. Kriteria Validitas Perangkat Pembelajaran

\begin{tabular}{|c|c|c|}
\hline No. & Kriteria & $\begin{array}{c}\text { Kategori } \\
\text { Keterlaksanaan RPP }\end{array}$ \\
\hline 1 & $85,01 \%-100 \%$ & Sangat Baik \\
\hline 2 & $70,01 \%-85 \%$ & Cukup Baik \\
\hline 3 & $50,01 \%-70 \%$ & Kurang Baik \\
\hline 4 & $01,00 \%-50 \%$ & Tidak Baik \\
\hline
\end{tabular}

(Adaptasi dari Akbar, 2013, p. 155)

Koefisien (indeks) kesepakatan antara dua observer, dihitung dengan rumus dari Cohen's Kappa seperti pada persamaan (1).

Data perkembangan sikap spiritual dan sosial siswa dianalisis dan dideskripsikan secara kualitatif yang menggambarkan perkembangan sikap yang ditampilkan oleh siswa selama berlangsungnya kegiatan pembelajaran.

Data hasil belajar aspek pengetahuan yang terdiri dari nilai pretest dan posttest dianalisis menggunakan analisis sensitivitas butir soal dan analisis $\mathrm{N}$-gain untuk mengetahui pengaruh pembelajaran terhadap hasil belajar aspek pengetahuan. Untuk analisis butir soal, suatu butir soal dinyatakan efektif dalam mengukur pengaruh pembelajaran terhadap hasil belajar jika bernilai lebih besar dari 0,3 ( $\mathrm{S}>0,3)$, sedangkan skor $\mathrm{N}$-gain yang diperoleh dicocokkan dengan kriteria N-gain pada Tabel 4 berikut.

Tabel 4. Kriteria Normalized Gain
\begin{tabular}{|c|c|}
\hline Skor $(\mathbf{g})$ & Kategori \\
\hline $\mathbf{0 , 7 0}<(\mathbf{g})$ & Tinggi \\
\hline $\mathbf{0 , 3 0} \leq(\mathbf{g}) \leq \mathbf{0 , 7 0}$ & Sedang \\
\hline$(\mathbf{g})<\mathbf{0 , 3 0}$ & Rendah \\
\hline
\end{tabular}

(Adaptasi dari Hake, 1999:1)

Data hasil belajar aspek keterampilan dari setiap siswa dibandingkan dengan kriteria ketuntasan minimal (KKM) yang ditetapkan oleh satuan pendidikan untuk mengetahui perkembangan hasil belajar siswa pada aspek keterampilan proses sains yang dinilai.

Instrumen yang digunakan dalam penelitian ini meliputi: (1) lembar validasi perangkat pembelajaran yang digunakan untuk memperoleh data skor validasi RPP, LKS, buku ajar siswa, dan instrumen penilaian hasil belajar; (2) lembar observasi, digunakan untuk memperoleh data skor keterlaksanaan RPP serta data kendala selama pembelajaran; (3) angket respon siswa, digunakan untuk memperoleh data respon siswa terhadap pembelajaran; (4) jurnal perkembangan sikap spiritual dan sikap sosial, digunakan untuk mengumpulkan data perkembangan sikap siswa selama pembelajaran; (5) tes pilihan ganda, digunakan untuk memperoleh data pretest dan posttest siswa pada aspek pengetahuan; dan (6) lembar penilaian kinerja, digunakan untuk mengumpulkan data hasil belajar siswa pada aspek keterampilan. 


\section{HASIL DAN PEMBAHASAN}

\section{A. Validitas Perangkat Pembelajaran}

Hasil validasi perangkat pembelajaran yang diperoleh dari dua orang validator dirangkum pada Tabel 5 berikut:

Tabel 5. Hasil Validasi Perangkat Pembelajaran

\begin{tabular}{|c|l|c|c|}
\hline No & \multicolumn{1}{|c|}{$\begin{array}{c}\text { Jenis Perangkat } \\
\text { Pembelajaran }\end{array}$} & Kategori & $(\boldsymbol{\kappa})$ \\
\hline 1 & $\begin{array}{l}\text { Rencana Pelaksanaan } \\
\text { Pembelajaran (RPP) }\end{array}$ & Sangat Valid & 0,48 \\
\hline 2 & $\begin{array}{l}\text { Lembar Kegiatan Siswa } \\
\text { LKS) }\end{array}$ & Sangat Valid & 0,47 \\
\hline 3 & Buku Ajar Siswa & Cukup Valid & 0,45 \\
\hline 4 & $\begin{array}{l}\text { Lembar Observasi Sikap } \\
\text { Spiritual }\end{array}$ & Sangat Valid & 1,00 \\
\hline 5 & $\begin{array}{l}\text { Lembar Observasi Sikap } \\
\text { Sosial }\end{array}$ & Sangat Valid & 0,55 \\
\hline 6 & $\begin{array}{l}\text { Lembar Penilaian Pretest } \\
\text { dan Posttest }\end{array}$ & Sangat Valid & 0,40 \\
\hline 7 & $\begin{array}{l}\text { Lembar Penilaian } \\
\text { Keterampilan }\end{array}$ & Sangat Valid & 0,47 \\
\hline
\end{tabular}

Keterangan: $(\kappa)$ : koefisien Cohen's Cappa

Berdasarkan data pada Tabel 5 di atas dapat disimpulkan bahwa perangkat pembelajaran inkuiri terbimbing berbantuan simulasi komputer materi atom, ion, dan molekul yang terdiri dari RPP, LKS, buku ajar siswa, lembar observasi sikap spiritual dan sikap sosial, Lembar Penilaian Pretest dan Posttest, serta lembar penilaian keterampilan layak untuk diimplementasikan dalam pembelajaran.

\section{B. Kepraktisan Perangkat Pembelajaran}

Aspek kepraktisan perangkat pembelajaran meliputi aspek keterlaksanaan RPP selama proses pembelajaran. Data hasil observasi keterlaksanaan RPP dirangkum pada Tabel 6 berikut.

Tabel 6. Hasil Observasi Keterlaksanaan RPP

\begin{tabular}{|c|c|c|c|c|c|c|c|c|}
\hline \multirow{2}{*}{$\begin{array}{c}\text { Aspek yang } \\
\text { Diamati }\end{array}$} & \multicolumn{2}{|c|}{ Pert. 1} & \multicolumn{2}{|c|}{ Pert. 2} & \multicolumn{2}{|c|}{ Pert. 3} & \multicolumn{2}{|c|}{ Rerata } \\
\hline & $\%$ & $\mathbf{P}$ & $\%$ & $\mathbf{P}$ & $\%$ & $\mathbf{P}$ & $\%$ & $\mathbf{P}$ \\
\hline $\begin{array}{l}\text { Kegitan } \\
\text { Pendahuluan }\end{array}$ & 96,9 & SB & 93,8 & SB & 96,9 & SB & 95,9 & SB \\
\hline Kegiatan Inti & 97,9 & SB & 95,8 & SB & 97,9 & SB & 97,2 & SB \\
\hline $\begin{array}{l}\text { Kegiatan } \\
\text { Penutup }\end{array}$ & 84,4 & SB & 84,4 & SB & 84,4 & SB & 84,4 & SB \\
\hline $\begin{array}{l}\text { Pengelolaan } \\
\text { waktu }\end{array}$ & 87,5 & SB & 100 & SB & 100 & SB & 95,8 & SB \\
\hline $\begin{array}{l}\text { Pengamatan } \\
\text { Suasana Kelas }\end{array}$ & 93,8 & SB & 90,6 & SB & 96,9 & SB & 93,8 & SB \\
\hline \multicolumn{9}{|l|}{ Keterangan: } \\
\hline$\%=$ Persen & & & . & & & & & \\
\hline $\mathrm{P}=$ Predik & & & $\mathrm{B}$ & $\mathrm{S}$ & gat & 3aik & & \\
\hline
\end{tabular}

Kegiatan pembelajaran diawali dengan apersepsi berupa tayangan slide berisi gambar (foto) setetes darah dan sekumpulan sel darah merah. Menurut Chatib (2012:92), apersepsi merupakan stimulus khusus pada awal belajar yang bertujuan meraih perhatian dari peserta didik. Gambar (foto) darah dan sel darah merah dipilih karena darah merupakan benda yang sudah familiar bagi siswa dan sel darah merah telah dipelajari sebelumnya di kelas VIII. Dengan melihat kedua gambar tersebut, siswa diharapkan segera dapat mengindentifikasinya. Tujuan menampilkan gambar ini adalah untuk mengarahkan siswa berpikir tentang benda-benda sangat kecil disekitarnya dan membandingkan ukurannya dengan benda yang lebih besar.

Kegiatan inti dimulai dengan fase penyajian masalah dan perumusan masalah oleh guru. Fase ini merupakan fase pertama dari pembelajaran model inkuiri (Eggen dkk, 2012:241). Pada pertemuan pertama, tahap ini dimulai dengan memberikan permasalahan kepada siswa berupa gambaran sekilas mengenai karakteristik atom yang berhubungan dengan muatan atom dan dasar pemberian nama suatu unsur. Pertanyaan diberikan kepada siswa untuk mengarahkan mereka melakukan eksperimen virtual mengenai apakah jumlah proton, neutron, atau elektron yang menjadi dasar para ilmuwan dalam memberikan nama terhadap suatu unsur serta partikel sub atom apa saja yang perubahan jumlahnya berpengaruh terhadap jenis dan jumlah muatan suatu atom.

Fase kedua dari kegiatan inkuiri adalah merumuskan hipotesis (jawaban sementara) dan menentukan variabel yang akan dimanipulasi, variabel respon, dan variabel kontrolnya. Hipotesis yang dirumuskan terkait dengan kegiatan percobaan penyelidikan pengaruh jumlah proton, neutron, dan elektron terhadap nama unsur, muatan, nomor atom, dan nomor massa pada LKS 1.

Fase ketiga adalah tahap mengumpulkan dan menganalisis data yang dimulai dengan kegiatan menentukan dan menuliskan prosedur pengambilan data, mengorganisasikan data ke dalam tabel hasil pengamatan serta menganalisis data. Fase keempat atau fase terakhir dari model inkuiri adalah kegiatan menilai hipotesis dan membuat kesimpulan mengenai apakah hipotesis yang mereka buat dapat diterima atau tidak berdasarkan hasil analisis data. Selanjutnya para siswa membuat generalisasi terhadap hasil percobaan sesuai dengan analisis data yang dilakukan oleh siswa.

Secara umum, tahapan-tahapan dalam kegiatan inti terlaksana dengan baik. Namun demikian, pada pertemuan pertama, para siswa masih kesulitan terutama dalam merumuskan hipotesis, mengidentifikasi variabel, dan merancang prosedur pengumpulan data sehingga membutuhkan bimbingan guru yang lebih intensif. Hal ini terjadi karena selama ini para siswa belum terbiasa belajar dengan model inkuiri dan masih dominan disuguhi dengan LKS yang terstruktur dan lengkap seluruh langkah dan variabel pengukurannya sehingga ketika diminta untuk mengembangkan sendiri prosedur percobaan, mereka mengalami kesulitan melakukannya. 
Menurut pendapat Trna dkk (2012:201), siswa harus mempunyai pengalaman pada level inkuiri yang lebih rendah agar dapat bekerja secara independen.

Rangkaian terakhir dari kegiatan pembelajaran adalah kegiatan penutup. Pada kegiatan penutup, guru dan siswa secara bersama-sama membuat kesimpulan mengenai kegiatan yang dilaksanakan dan materi yang telah dipelajari. Selain itu guru juga memberikan kesempatan kepada siswa untuk menanyakan aktivitasaktivitas atau materi yang perlu diperdalam penjelasannya atau yang masih kurang dimengerti oleh siswa.

\section{Keefektifan Perangkat Pembelajaran}

Keefektifan perangkat pembelajaran mencakup hasil belajar siswa (aspek sikap spiritual dan sikap sosial, aspek pengetahuan, dan aspek keterampilan) dan respon siswa terhadap komponen-komponen pembelajaran.

a. Hasil belajar siswa

1) Aspek Sikap Spiritual dan Sikap Sosial

Ditinjau dari butir sikap ketaqwaan pada aspek sikap spiritual, akumulasi jurnal observasi perkembangan siswa yang diamati oleh dua orang observer selama kegiatan pembelajaran (tiga kali pertemuan) menunjukkan bahwa 21 orang siswa telah memperlihatkan perilaku yang konsisten selama mengikuti kegiatan pembelajaran, sedangkan 3 orang lainnya belum menampilkan perilaku yang konsisten pada pertemuan awal. Setelah mendapatkan bimbingan dari guru, pada pertemuan selanjutnya perilaku yang ditampilkan oleh ketiga siswa tersebut telah berkembang menuju baik dengan menampilkan perilaku yang sesuai dengan indikator secara lebih konsisten. Pada butir sikap bersyukur, keseluruhan siswa telah memperlihatkan perilaku yang konsisten selama mengikuti kegiatan pembelajaran sesuai dengan indikator butir sikap yang dinilai.

Ditinjau dari butir sikap jujur pada aspek sikap sosial, keseluruhan siswa telah memperlihatkan perilaku yang konsisten selama mengikuti kegiatan pembelajaran sesuai dengan indikator butir sikap yang dinilai. Selanjutnya pada butir sikap disiplin, sebanyak 20 orang siswa juga telah menampilkan perilaku yang konsisten sesuai dengan indikator yang ditentukan selama kegiatan pembelajaran berlangsung, dan sebanyak 4 orang siswa terlihat sedikit berbeda konsistensinya menurut penilaian para observer dimana keempat siswa tersebut terlihat belum menampilkan perilaku yang konsisten pada pertemuan awal. Setelah mendapatkan bimbingan dari guru, pada pertemuan selanjutnya perilaku yang ditampilkan oleh seluruh siswa telah berkembang menuju baik dengan menampilkan perilaku yang sesuai dengan indikator secara lebih konsisten.
Perlu diperjelas disini bahwa perkembangan sikap siswa yang diamati dalam kegiatan pembelajaran inkuiri terbimbing berbantuan simulasi komputer ini belum bisa dikatakan bersifat permanen karena hanya berlangsung selama tiga kali kegiatan pembelajaran. Penilaian akhir sikap sendiri dilakukan pada akhir setiap semester sesuai dengan panduan Permendikbud Nomor 53 Tahun 2015.

2) Aspek Pengetahuan

Peningkatan hasil belajar siswa yang mengindikasikan efek (pangaruh) pembelajaran dapat diketahui dari hasil perhitungan $N$-gain. Analisis N-gain terhadap nilai pretest dan posttest siswa yang berada pada rentang antara 0,6 sampai dengan 0,9 dengan kategori tinggi sebanyak 16 orang siswa dan kategori sedang sebanyak 8 orang siswa menunjukkan adanya peningkatan secara signifikan pada aspek pengetahuan dimana rata-rata nilai posttest-nya jauh lebih tinggi daripada nilai pretest-nya. Hasil analisis N-Gain dapat dilihat pada Grafik 1 berikut ini.

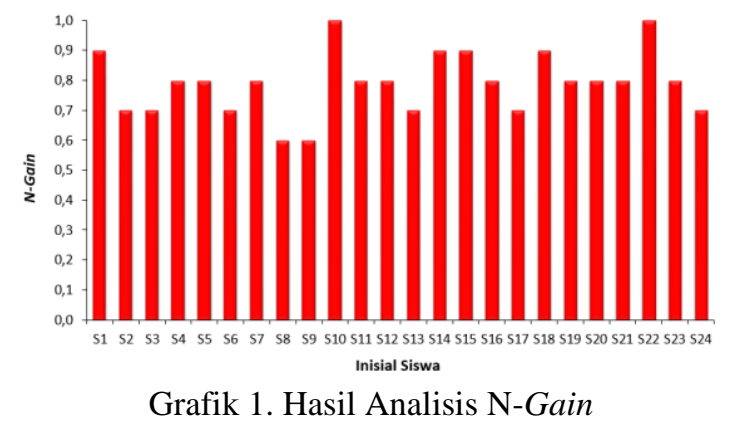

Tes hasil belajar aspek pengetahuan yang dikembangkan juga dinilai sensitivitasnya untuk menentukan apakah pembelajaran inkuiri terbimbing berbantuan simulasi komputer memberikan efek yang positif terhadap pembelajaran. Analisis sensitivitas butir soal menunjukkan perolehan skor dengan rentang antara 0,4 sampai dengan 0,8 dengan kategori sensitif. Hal tersebut mengindikasikan setiap butir soal yang dikembangkan memiliki kepekaan yang cukup terhadap efek pembelajaran yang diberikan serta juga berarti bahwa pembelajaran memberikan efek yang positif terhadap peningkatan hasil belajar aspek pengetahuan siswa. Data hasil analisis sensitivitas butir soal disajikan pada Grafik 2 dibawah ini.

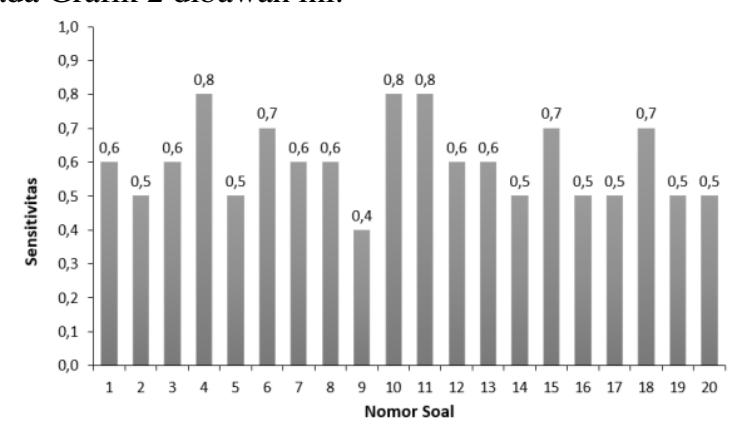

Grafik 2. Hasil Analisis Sensitivitas Butir Soal 
Terjadinya peningkatan yang signifikan pada hasil belajar aspek pengetahuan setelah siswa menerima materi dengan model inkuiri terbimbing berbantuan simulasi komputer memang sangat dimungkinkan karena pembelajaran inkuiri mengembangkan pendekatan pembelajaran berpusat kepada siswa (student-centered approach).

Model belajar inkuiri memungkinkan siswa untuk terlibat secara langsung dalam memeroleh sendiri ide-ide atau pengetahuan baru melalui serangkaian kegiatan yang mereka geluti serta mengonstruksi pengetahuannya sendiri. Pengkondisian belajar inkuiri mengadopsi salah satu gagasan pokok teori konstruktivisme dalam pendidikan yaitu bahwa pembelajaran merupakan konstruksi pengetahuan. Pembelajaran bukan sekadar proses menyerap informasi, gagasan, dan keterampilan, tetapi materi-materi baru tersebut akan dikonstruksi oleh otak (Joyce dkk, 2011:13-14).

Ditinjau dari media yang digunakan, peningkatan hasil belajar siswa juga dipengaruhi oleh pemanfaatan media simulasi komputer dalam proses pembelajaran. Aplikasi simulasi komputer seperti PhET, Jmol, dan Periodic Table yang bersifat interaktif dan kaya informasi memungkinkan siswa melakukan observasi dan penyelidikan sendiri untuk menyelesaikan masalah di LKS dengan jalan memanipulasi variabel-variabel yang terdapat di dalam aplikasi simulasi komputer yang digunakan. Simulasi komputer yang digunakan dalam pembelajaran ini juga membuat keadaan-keadaan abstrak (tidak dapat diamati secara langsung) seperti struktur internal atom, konfigurasi elektron, model molekul, dan ion menjadi terkesan lebih riil karena divisualisasikan secara dua dan tiga dimensi.

Pembelajaran berbantuan simulasi komputer memberikan kesan yang lebih mendalam, menyenangkan, dan lebih memudahkan siswa memahami konsep-konsep keilmuan yang dipelajarinya dibandingkan dengan pembelajaran tanpa menggunakan media simulasi komputer.

Penelitian inkuiri berbantuan perangkat multimedia (aplikasi simulasi komputer mengenai pergerakan bumi) juga dilakukan oleh Winnie dan Cheung (2007:329) terhadap dua kelompok siswa di hongkong. Hasil penelitiannya menunjukkan bahwa hasil belajar siswa dari kelompok yang diberikan bimbingan lebih banyak meningkat lebih signifikan dibandingkan dengan hasil belajar siswa dari kelompok yang tidak diberikan bimbingan.

Penelitian yang lain dilakukan oleh Olde dkk (2013:47) dengan cara membandingkan peningkatan pengetahuan konseptual dan pengetahuan prosedural antara dua kelompok siswa yang diberi pembelajaran dengan metode yang berbeda pada materi listrik. Salah satu kelas diberikan pembelajaran menggunakan model inkuiri berbantuan simulasi komputer, sedangkan kelas lainnya menggunakan simulasi komputer yang sama diajar dengan model tradisional. Setelah diberi posttest, hasilnya menunjukkan bahwa pengetahuan konseptual siswa yang diajar menggunakan model inkuiri meningkat lebih signifikan dibandingkan dengan siswa yang diajar menggunakan model tradisional, sedangkan pada aspek pengetahuan prosedural, tidak dijumpai perbedaan diantara keduanya.

\section{3) Aspek Keterampilan}

Penilaian aspek keterampilan siswa berupa penilaian kinerja. Keterampilan yang dinilai dalam penelitian ini adalah keterampilan proses sains. Penilaian keterampilan proses mencakup penilaian terhadap kemampuan siswa dalam melakukan observasi dan mengidentifikasi benda-benda berbahan plastik berdasarkan jenis material penyusunnya yang biasa digunakan dalam kehidupan sehari-hari, kemampuan mengorganisasikan data ke dalam tabel hasil pengamatan, kemampuan menganalisis data mengenai kesesuaian antara penggunaan bahan-bahan berbahan plastik di lingkungan sekitar dengan fungsi yang sebenarnya terkait dengan pengaruhnya terhadap kesehatan, serta kemampuan menarik kesimpulan berdasarkan data hasil pengamatan. Selain itu dilakukan juga penilaian terhadap laporan hasil penyelidikan siswa.

Analisis data hasil belajar aspek keterampilan menunjukkan bahwa seluruh siswa telah mencapai ketuntasan dengan rentang nilai antara 75 sampai dengan 100 dan predikat A sebanyak 14 orang siswa, sedangkan predikat B sebanyak 10 orang siswa. Setiadi dan Muflika (2012:258) yang melakukan penelitian dengan media simulasi PhET berbasis inkuiri terbimbing menemukan bahwa PhET dengan arahan guru atau fasilitator dapat digunakan untuk mengembangkan keterampilan proses sains siswa SMA.

\section{b. Respon Siswa}

Data respon siswa diperoleh dari angket respon yang diberikan kepada siswa setelah pelaksanaan kegiatan pembelajaran. angket tersebut merekam pendapat siswa mengenai ketertarikan mereka terhadap komponen-komponen pembelajaran seperti materi pelajaran, buku ajar, LKS, media pembelajaran, suasana kelas, dan cara guru mengajar. Angket respon siswa juga berisi pertanyaan mengenai kebaruan komponenkomponen pembelajaran seperti yang diuraikan di atas, pendapat siswa mengenai bimbingan guru dalam menyelesaikan kegiatan LKS, serta pendapat mereka mengenai buku ajar dan lembar penilaian yang digunakan. Berdasarkan analisis data respon siswa, 91,5\% siswa memberikan tanggapan positif terhadap komponen-komponen pembelajaran, sedangkan 8,5\%

Pengembangan Perangkat Pembelajaran Inkuiri 1376 Terbimbing Berbantuan Simulasi ........... 
memberikan tanggapan negatif terhadap komponen pembelajaran.

\section{Temuan Penelitian}

Berdasarkan hasil analisis data dan pembahasan hasil penelitian dari pengembangan dan penerapan perangkat pembelajaran inkuiri terbimbing berbantuan simulasi komputer materi atom, ion, dan molekul untuk meningkatkan hasil belajar siswa, maka diperoleh temuan penelitian sebagai berikut:

1. Validitas perangkat pembelajaran yang dikembangkan.

Perangkat pembelajaran inkuiri terbimbing berbantuan simulasi komputer yang terdiri dari RPP, LKS, buku ajar siswa, dan instrumen penilaian hasil belajar dinyatakan valid dan dapat digunakan dalam kegiatan pembelajaran.

2. Kepraktisan perangkat pembelajaran yang dikembangkan berdasarkan aspek:

a. keterlaksanaan RPP pada pertemuan 1 sampai pertemuan 3 secara keseluruhan terlaksana dengan kategori sangat baik.

b. siswa menunjukkan respon positif terhadap komponen-komponen pembelajaran inkuiri terbimbing berbantuan simulasi komputer.

3. Keefektifan perangkat pembelajaran yang dikembangkan berdasarkan hasil belajar siswa pada aspek sikap spiritual, sikap sosial, pengetahuan, dan keterampilan.

a. penerapan perangkat pembelajaran inkuiri terbimbing berbantuan simulasi komputer dapat mengembangkan aspek sikap spiritual dan sikap sosial siswa.

b. pembelajaran inkuiri terbimbing berbantuan simulasi komputer dapat meningkatkan hasil belajar pada aspek pengetahuan siswa. Peningkatan hasil belajar dapat dilihat dari ratarata $N$-gain sebesar 0,79 dengan kategori tinggi.

c. penerapan perangkat pembelajaran inkuiri terbimbing berbantuan simulasi komputer dapat mengembangkan aspek keterampilan siswa dengan nilai rata-rata 87,3 .

\section{PENUTUP}

\section{A. Simpulan}

Berdasarkan temuan hasil penelitian dapat disimpulkan bahwa perangkat pembelajaran inkuiri terbimbing berbantuan simulasi komputer (PhET, Jmol, dan Periodic Table) yang dikembangkan layak digunakan untuk meningkatkan hasil belajar siswa SMP pada materi atom, ion, dan molekul.

\section{B. Saran}

Berdasarkan hasil penelitian yang telah dilakukan, beberapa saran yang dapat dikemukakan oleh peneliti adalah sebagai berikut:

1. Pengembangan perangkat pembelajaran inkuiri terbimbing berbantuan simulasi komputer perlu dikembangkan secara luas pada materi pembelajaran IPA lainnya untuk penelitian selanjutnya.

2. Instrumen penilaian hasil belajar sebaiknya juga dikembangkan untuk mengukur peningkatan hasil belajar pada aspek keterampilan siswa.

\section{DAFTAR PUSTAKA}

Abruscato, J., \& DeRosa, D.A. (2009). Teaching Children Science: Discovery Methods for the Elementary and Middle Grades (3rd Ed). Boston: Allyn \& Bacon/Pearson.

Akbar, S. (2013). Instrumen Perangkat Pembelajaran. (Holid, A., Ed.). Bandung: Remaja Rosdakarya.

Bakerman, R., \& Gottman, J.M. (1997). Observing Interaction: An Introduction to Sequential Analysis ( $2^{\text {nd }}$ ed.). New York: Cambridge University Press.

Banchi, H., \& Bell, R. (2008). The Many Level of Inquriy. Science and Children. 46(2), 26-29.

Bell, L.R., Newsome, J.G., \& Luft, J. (Eds.). (2008). Technology in the Secondary Science Classroom. Virginia: NSTA Press.

Chatib, M. (2012). Gurunya Manusia. Bandung: PT. Mizan Pustaka.

Eggen, P., \& Kauchak, D. (2012). Strategies and Models for Teachers: Teaching Content and Thinking Skills ( $6^{\text {th }}$ ed.) Boston: Pearson.

Hake. (1999). Analyzing change/gain scores. (Online). Diunduh dari: http://www. physicsindiana.edu/sdi/Analyzing-Change-Gain. pdf.

Joyce, B., Weil, M., \& Calhoun, E. (2009). Models of Teaching ( $8^{\text {th }}$ ed.). (Fawaid, A., \& Mirza, A., Penerjemah). Yogyakarta: Pustaka Pelajar.

Kuhlthau, C.C., Maniotes, L.K., \& Caspari, A.K. (2007). Guided Inquiry: Learning in the $21^{\text {st }}$ Century. Westport, CT: Libraries Unlimited.

Landis, J.R., \& Koch, G.G. (1977). The Measurement of Observer Agreement for Categorical Data. Biometrics. 33(1), 159-174.

Olde, C.V.D., Jong, T.D., \& Gijlers, H. (2013). Learning by Design Instruction in the Context of Simulationbased Inquiry Learning. Educational Technology and Society. 16(4), 47-58.

Opara, J.A., \& Oguzor, N.S. (2011). Inquiry Instructional Method and the School Science Curriculum. Current Research Journal of Social Sciences. 3(3), 188-198. 
Pradianti, D. (2015). Pengembangan Perangkat Pembelajaran Fisika Berbasis Inkuiri Terbimbing untuk Melatihkan Kinerja Ilmiah Siswa. Jurnal Penelitian Pendidikan Sains. 4( 2), 672-680.

Setiadi, R., \& Muflika, A.A. (2012). Eksplorasi Pemberdayaan Courseware Simulasi PhET untuk Membangun Keterampilan Proses Sains Siswa SMA. Jurnal Pengajaran MIPA. 17(2), 258-268.

Sudjana, N., \& Rivai, A. (2013). Media Pengajaran. Bandung: Sinar Baru Algesindo.
Trna, D; Trnova, E \& Sibor, J. (2012). Implementation of Inquiry-Based Science Education in Science Teacher Training. Journal of Educational and Instructional Studies in the World, 199-209.

Winnie, W.M., \& Cheung, K.S. (2007). Approaches of Inquiry Learning with Multimedia Resource in Primary Classrooms. Journal of Computers in Mathematics and Science Teaching. 26(4), 329-354. 